\title{
Kepadatan Aedes Sp (Container Indexs) Setelah Penerapan Modifikasi Perangkap Vektor
}

\author{
Deky Wicaksono ${ }^{1}$, Iskandar Arfan ${ }^{2}$, Selviana $^{3}$ \\ 1,2,3 Prodi Kesehatan Masyarakat Universitas Muhammadiyah Pontianak \\ Email Korespondensi: iskandar_arfan@yahoo.com
}

Tanggal submisi: 11 Desember 2020: Tanggal penerimaan: 18 Februari 2021

\begin{abstract}
ABSTRAK
Kepadatan populasi nyamuk di suatu lingkungan menggambarkan potensi penularan DBD. Upaya dalam pengendalian DBD berfokus kepada pengendalian vektor. Penelitian ini bertujuan mengetahui perbedaan rerata kepadatan populasi larva Aedes spp sebelum dan sesudah penggunaan perangkap vektor di desa ambangah Kabupaten Kubu Raya. Jenis penelitian ini adalah analitik dengan rancangan penelitan pre ekperiment. Subjek penelitian ini adalah 50 rumah yang dipilih secara acak dari 5 RW terpilih berdasarkan data kasus DBD, 1 RW dipilih sebanyak 10 rumah dan dipasang 2 ovitrap total ovitrap sebanyak 100 buah ovitrap. Analisis data dilakukan menggunakan uji dependent t-test/ paired sample t-test. Hasil: 4 minggu sebelum intervensi rata-rata CI 63,25\% dan 4 minggu setelah intervensi rata-rata CI 39,75\%. Hasil uji statistik didapatkan nilai $p=$ $0,001<0,05$ maka dapat disimpulkan terdapat perbedaan populasi jentik Aedes Spp yang bermakna antara sebelum intervensi dengan sesudah intervensi. Simpulan: Perangkap dapat digunakan oleh masyarakat dalam upaya pengendalian vektor sederhana. Perangkap vektor mampu menurunkan kepadatan populasi Aedes spp dan risiko penularan DBD.
\end{abstract}

Kata Kunci : Perangkap Vektor, Kepadatan Vektor (Container Index), Aedes Sp

\begin{abstract}
The mosquito population density in an environment illustrates the potential for dengue transmission. Effort in DHF control focuses on vector control. This study aims to determine the difference in mean Population density of Aedes spp larvae before and after the use of vector traps in the village of ambangah Kubu Raya Regency. This type of research is analytical with a pre-experimental research design. The subjects of this study were 50 houses selected from 5 selected $R W s$ Based on DHF case data, 10 houses were selected 1 RW and 2 ovitraps were installed, totaling 100 ovitraps. Data analysis was performed using dependent $t$ test / paired sample t-test. Result:4 weeks before the intervention the average CI was $63.25 \%$ and 4 weeks after the intervention the average CI was $39.75 \%$. The results of statistical tests obtained $p$ value $=0.001<0.05$, it can be concluded that there are significant differences in the Aedes Sp larva population (Container index) between before and after the intervention. Conclusion: Traps can used by
\end{abstract}


the public in simple vector control efforts. Trap vector can reduce density Aedes spp population and risk of dengue transmission

Keywords: Trap Vector, Density vector (Container index), Aedes sp

ISSN 1979-7621 (Print). ISSN 2620-7761 (Online).

DOI : $10.23917 /$ jk.v14i1.12891

\section{PENDAHULUAN}

Derajat kesehatan masyarakat dipengaruhi oleh 4 faktor yaitu : faktor lingkungan, faktor perilaku, faktor pelayanan kesehatan, dan faktor keturunan. Upaya perbaikan kesehatan masyarakat terus ditingkatkan antara lain melalui pencegahan dan pemberantasan penyakit menular yang masih menjadi masalah kesehatan masyarakat. Salah satu dari masalah tersebut adalah Penyakit Demam Berdarah Dengue (DBD) (Soekiman, 2012)

Demam Berdarah Dengue (DBD) adalah demam yang paling sering menyerang anak yang berusia kurang dari 15 tahun serta orang rang dewasa. DBD ini ditandai dengan gejala demam yang tinggi pemecahan pembuluh darah yang menyebabkan turunnya trombosit seorang penderita sehingga menimbulkan syok yang sangat fatal (WHO, 2011)

Vektor Borne Disease masih menjadi masalah kesehatan dunia, lebih dari $17 \%$ semua penyakit menular dikarenakan oleh vektor. Menyebabkan lebih dari 1 juta kematian setiap tahunnya. Data dari seluruh dunia menunjukan Asia menempati urutan pertama dalam jumlah penderita DBD (WHO, 2019)

Berdasarkan data Dinas Kesehatan Provinsi Kalbar kasus DBD Kabupaten Kubu Raya menempati urutan ke 3 terbesar sebanyak $376(12,03 \%)$ kasus DBD setelah kabupaten Ketapang yaitu sebanyak $808 \quad(25,86 \%)$ kasus dan Kabupaten Kapuas Hulu sebanyak 470 $(15,04 \%)$ kasus (Dinkes Provinsi KALBAR, 2018).

Salah satu metode yang dapat digunakan sebagai alat survey dan alat pengendalian vektor nyamuk yang disarankan oleh WHO adalah perangkap telur nyamuk atau ovitrap. Ovitrap (oviposition trap) merupakan sebuah perangkap telur nyamuk yang terdiri dari wadah berisi air untuk memerangkap telur nyamuk. Alat ini dikembangkan pertama kali oleh Fay dan Eliaon yang kemudian digunakan oleh Central For Diseases control and Prevention(CDC) untuk surveilans Aedes sp dalam menurunkan densitas vektor di beberapa negara tanpa harus menggunakan bahan insektisida (A Polson et al., 2002)

Ovitrap telah dikembangkan secara meluas di berbagai negara untuk memonitoring penyebaran jentik/larva DBD. Dengan cara ini, tidak hanya nyamuk dapat dibunuh secara efektif, tapi juga kepadatan nyamuk untuk mengendalikan popularisasi penyakit seperti demam berdarah dan sejenisnya (Karp, et all, 2012)

Penggunaan dan modifikasi ovitrap telah banyak dilakukan di berbagai negara (Hamzah and Basri, 2016). Ovitrap mudah dilakukan dan dapat diterapkan di mana saja dan tidak menimbulkan dampak negatif pada lingkungan seperti halnya pengasapan (Rati and Rustam, 2016).

Berdasarkan

penelitian sebelumnya yang dilakukan oleh (Arfan, 2020) di Desa Kuala Dua Kabupaten Kubu Raya mengenai perbedaan jenis ovitrap berantraktan terhadap jumlah telur aedes mendapatkan hasil bahwa ovitrap ember plastik dengan attraktan rendaman jerami paling berpengaruh terhadap jumlah telur yang terperangkap. Penelitian ini bertujuan untuk mengetahui 
keefektifan modifikasi perangkap vektor dari botol plastic dengan atraktan rendaman jerami untuk membunuh larva sekaligus nyamuk dewasa melihat efek nya terhadap indeks kapadatan vektor (Container index).

\section{METODE}

Penelitian ini merupakan eksperimen semu (quasi eksperimen) Dilakukan pada bulan Juli - September 2020 di desa ambangah kabupaten Kuburaya Kalimantan Barat.

\subsection{Metode Pengumpulan data}

Populasi dalam penelitian ini adalah 321 rumah dari 5 RW di desa ambangah. Sampel di ambil dengan quota sampling sebanyak 50 rumah, dengan masing-masing RW sebanyak 10 rumah, 1 rumah diletakkan 2 perangkap modifikasi ovitrap dengan total sebanyak 100 perangkap modifikasi ovitrap.. Variabel dependen dalam penelitian ini adalah Kepadatan vector (Container index) sedangkan variabel independent dalam penelitian ini adalah modifikasi perangkap vektor yang terbuat dari botol plastic berisi atraktan rendaman jerami. Penelitian ini menggunakan lembar observasi sebagai instrument pengumpulan data Pengambilan data dilakukan selama 8 minggu yakni 4 minggu sebelum intervensi dan 4 minggu setelah intervensi dengan melihat jentik di penampungan air untuk mengetahui Container index pada 50 rumah sebelum dan sesudah penerapan perangkap.

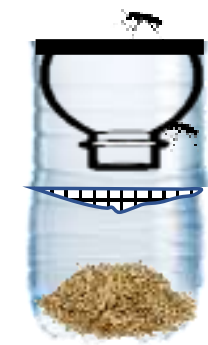

\section{Gambar 1 Modifikasi perangkap ovitrap}

\subsection{Metode Analisa Data}

Analisa dilakukan dengan aplikasi computer dengan menggunakan Uji T-tes dengan tingkat kepercayaan $95 \%$ dan tingkal kesalahan 5\%. Perangkap vektor

\section{HASIL DAN PEMBAHASAN}

Dari hasil penelitian yang telah dilakukan pada masing-masing 100 ovitrap yang dilakukan selama 8 minggu yakni 4 minggu sebelum intervensi ratarata CI 63,25\% dan 4 minggu setelah intervensi rata-rata CI $39,75 \%$, terjadi penurunan CI secara bertahap untuk lebih jelas dapat diliihat pada tabel dan grafik di bawah ini

Tabel 1 Distribusi frekuensi Container Index Terpasang

\begin{tabular}{llccc}
\hline No & Pengamatan & $\begin{array}{c}\text { Jumlah } \\
\text { Perangkap } \\
\text { Terpasang }\end{array}$ & $\begin{array}{c}\text { Jumlah } \\
\text { Perangkap } \\
\text { Positif Jentik }\end{array}$ & $\begin{array}{c}\text { Container } \\
\text { Index }\end{array}$ \\
\hline 1 & Minggu 1 & 100 & 501 & $64 \%$ \\
2 & Minggu 2 & 100 & 420 & $61 \%$ \\
3 & Minggu 3 & 100 & 384 & $63 \%$ \\
4 & Minggu 4 & 100 & 370 & $65 \%$ \\
5 & Rerata CI sebelum intervensi & $\mathbf{6 3 , 2 5 \%}$ \\
6 & Minggu 5 & 100 & 194 & $51 \%$ \\
7 & Minggu 7 & 100 & 110 & $46 \%$ \\
8 & Minggu 8 & 100 & 62 & $36 \%$ \\
\multicolumn{7}{r}{ Rerata CI setelah intervensi } & $26 \%$ \\
\hline
\end{tabular}

Grafik 1 Container Index sebelum dan sesudah intervensi 


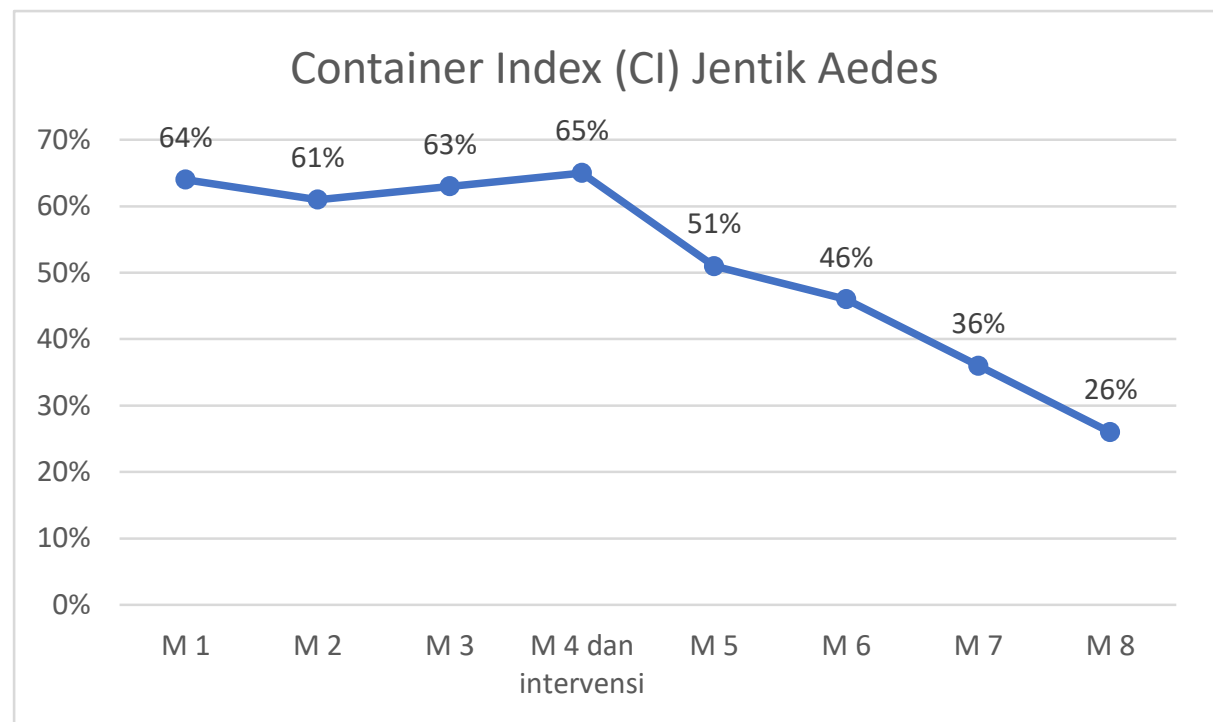

Tabel 2

Hasil Analisis Wilxocon populasi aedes sp sebelum dan sesudah intervensi

\begin{tabular}{ccccc}
\hline Variabel & $\mathrm{n}$ & $\begin{array}{c}\text { Median } \\
\text { (minimum- } \\
\text { maksimum) }\end{array}$ & Rerata \pm s.b. & $\begin{array}{c}P \\
\text { value }\end{array}$ \\
\hline $\begin{array}{c}\text { Populasi Jentik } \\
\text { sebelum intervensi }\end{array}$ & 100 & $22(0-38)$ & $\begin{array}{c}16,75 \pm \\
12,38\end{array}$ & 0,001 \\
$\begin{array}{c}\text { Populasi Jentik setelah } \\
\text { intervensi }\end{array}$ & 100 & $4(0-12)$ & $4,03 \pm 3,36$ & \\
\hline
\end{tabular}

Dari tabel 1 dan grafik 1 di dapatkan rata-rata $\mathrm{CI}$ sebelum intervensi yakni 63,25\% dan setelah intervensi rata-rata CI $39,75 \%$. Penurunan CI dimulai pada minggu ke 5 (51\%) sampai minggu ke 8 menjadi (26\%).

Diketahui tabel 2 pada hasil analisis yang didapatkan nilai tengah dari populasi jentik sebelum intervensi yakni 22 dengan nilai rerata 16,75 dan variasi distribusi sebesar 12,38, sedangkan nilai tengah dari populasi jentik setelah intervensi adalah 4 dengan nilai rerata 4,03 dan variasi distribusi sebesar 3,36. Hasil uji statistik didapatkan nilai $p=0,001<0,05$ maka dapat disimpulkan terdapat perbedaan populasi jentik Aedes Spp (Container index) sebelum dan sesudah intervensi.

Perangkap modifikasi vektor dalam penelitian ini adalah salah satu inovasi teknologi Tepat Guna dengan memodifikasi botol plastik dengan atraktan rendaman jerami yang digunakan untuk pengendalian nyamuk. Prinsip kerja alat ini merupakan kombinasi cara kerja ovitrap dan larvitap dengan membuat breeding places Ae. aegypti untuk bertelur dan telur tidak bisa berkembang serta nyamuk dewasa tidak dapat keluar dari perangkap.kemudian mati.

Berdasarkan analisis wilcoxon yang dilakukan hasil uji statistik didapatkan terdapat perbedaan populasi jentik Aedes Sp (Container insex) sebelum dan sesudah intervensi.

Kepadatan populasi Aedes $s p$ (Container Index) sesudah penggunaan perangkap modifikasi vektor secara keseluruhan mengalami penurunan dibandingkan dengan kepadatan populasi Aedes spp yang diukur sebelum 
penggunaan perangkap. Penurunan CI secara bertahap di mulai pada pengamatan minggu ke 5 setelah intervensi dari $65 \%$ menjadi $51 \%$ kemudian 46\%, 36\%, dan menjadi $26 \%$, Walaupun terjadi penurunan namun indicator CI tersebut masih belum mencapai batas yang ditetapkan oleh WHO dan Kemenkes. World Health Organization (WHO) menetapkan HI $<1 \%$, CI $<5 \%$, dan BI $<50 \%$ suatu wilayah dapat dikatakan risiko rendah untuk penularan DBD (Kemenkes, 2010).

Penurunan kepadatan populasi Aedes sp pada penelitian ini sejalan dengan penelitian yang dilakukan oleh (Ramadhani T, Santoso B, Priyanto D and BF, 2012) bahwa terdapat perbedaan rerata penurunan indikator entomologi/ kepadatan populasi Aedes sp setelah penggunaan ovitrap, pada penelitian tersebut menggunakan Lethal Ovitrap yang ovistripnya mengandung zat Cypermethrin yang dapat mempengaruhi ketahanan hidup telur nyamuk berada di dalamnya.

Kepadatan populasi Aedes sp pada suatu wilayah dapat dipengaruhi oleh beberapa faktor seperti perilaku partisipasi masyarakat dalam kegiatan Pemberantasan Sarang Nyamuk Terpadu (PSN Terpadu) yang masih kurang (Kemenkes, 2010). Beberapa penelitian mengungkapkan tingginya populasi vektor di karenakan masyarakat tidak menerapkan program PSN 3M plus sesuai dengan anjuran pemerintah seperti

\section{KESIMPULAN}

Berdasarkan hasil dan pembahasan dapat di simpulkan bahwa 4 minggu sebelum intervensi rata-rata $\mathrm{CI}$ $63,25 \%$ dan 4 minggu setelah intervensi rata-rata CI $39,75 \%$. Terdapat perbedaan populasi jentik Aedes $S p$ sebelum dan sesudah intervensi. Sehingga perangkap vector dapat tidak menguras bak mandi dengan teratur/ cara menguras bak mandi yang masih kurang tepat atau kebiasaan membiarkan berbagai kontainer terbuka sehingga bisa menjadi tempat perkembangbiakan nyamuk serta tidak mengubur sampah- sampah yang dapat menampung air hujan. risiko lain seperti curah hujan, kurangnya perhatian masyarakat terhadap sanitasi lingkungan, keberadaaan TPA potensial dapat meningkatkan kepadatan populasi Aedes $s p$ yang berujung pada peningkatan KLB penyakit DBD (Aditama W, 2015). Menurut (Sari, P., dan M., 2012) nyamuk Aedes sp pada umum nya menyukai genangan yang air yang tertampung di suatu wadah yang disebut kontainer atau tempat penampungan air (TPA) bukan genangan air ditanah.

Kepadatan jentik nyamuk Aedes spp di suatu kawasan harus dikontrol dan dengan penanganan yang tepat dengan melakukan pemutusan rantai penularan dan mengendalikan populasi vektor DBD (Fathi., S. Keman, 2005). Berdasarkan hasil bahwa perangkap modifikasi ini dapat menurunkan kepadatan aedes sp (Container index) maka diharapkan masayarakat dapat memanfaatkan dan menerapkan perangkap modifikasi vektor ini untuk mengendalikan populasi vektor DBD dan menjadi langkah preventif untuk memutus rantai perkembangbiakan vektor nyamuk pembawa virus penyakit DBD. 


\section{DAFTAR PUSTAKA}

A Polson, K. et al. (2002) 'The Use of Ovitraps Baited with Hay Infusion as a Surveillance Tool for Aedes aegypti Mosquitoes in Cambodia.', p. Dengue Bulletin. 2002 Dec; 26: 178-184.

Aditama W, Z. (2015) 'Efektivitas ovitrap bambu terhadap jumlah jentik Aedes sp yang terperangkap.', Jurnal Kesehatan Masyarakat Nasional, 9(4), pp. 369-374.

Dinkes Provinsi KALBAR (2018) Profil Kesehatan Dinkes Kalbar Tahun 2018. Pontianak, Kalimantan Barat.

Fathi., S. Keman, dan C. U. W. (2005) 'Peran faktor lingkungan dan perilaku terhadap penularan demam berdarah dengue di Kota Mataram', Jurnal Kesehatan Lingkungan, 2(1), pp. 1-10.

Hamzah, E. and Basri, S. (2016) 'Perbedaan Ovitrap Indeks Botol , Ember dan Port Mosquito Trap sebagai Perangkap Nyamuk Aedes sp . di Area Kantor Kesehatan Pelabuhan Kelas II Samarinda Wilayah Kerja Sangatta Kabupaten Kutai Timur', 2(higiene), p. 3.

Karp, J. M., Vemula, P. K. and Anderson, R. R. (2012) 'US 2012/0321573'. doi: $10.1037 / \mathrm{t} 24245-000$.

Kemenkes, R. (2010) Pemberantasan nyamuk penular demam berdarah dengue. Jakarta.

Ramadhani T, Santoso B, Priyanto D, P. A. and BF, W. (2012) Aplikasi (lethal ovitrap) dalam upaya pengendalian vektor demam berdarah dengue di daerah endemis DBD. Jakarta.

Rati, G. and Rustam, E. (2016) 'Penelitian Perbandingan Efektivitas Berbagai Media Ovitrap terhadap Jumlah Telur Aedes Spp yang Terperangkap di Kelurahan Jati Kota Padang', Jurnal Kesehatan Andalas, 5(2), pp. 385-390.

Sari, P., dan M., P. G. (2012) 'Hubungan kepadatan jentik Aedes sp dan praktik psn dengan kejadian DBD di sekolah tingkat dasar di kota Semarang', Jurnal Kesehatan Masyarakat, 1(2), pp. 413-422.

Soekiman, S. (2012) Demam Berdarah Dengue. Sagung Seto.

WHO (2011) Comprehensive guidelines for prevention and control of dengue and dengue haemorrhagic fever, WHO Regional Publication SEARO. doi: 10.1017/CBO9781107415324.004.

WHO (2019) Dengue and severe dengue. 